\title{
PERLINDUNGAN HUKUM KORBAN PENIPUAN TRANSAKSI JUAL BELI ONLINE MELALUI GANTI RUGI SEBAGAI PIDANA TAMBAHAN
}

\section{"Legal Protection For The Fraudulent Victims Of Online Trading Transactions Trought Recoupment As Additional Pinalty"}

\author{
Silvony Kakoe, Masruchin Ruba'I, Abdul Madjid \\ Pascasarjana Ilmu Hukum Universitas Brawijaya Malang Jawa Timur, Indonesia. \\ Korespondensi email: $\underline{\text { silvonykakoe@gmail.com }}$
}

\begin{abstract}
ABSTRAK
Kewajiban ganti rugi terhadap korban pada dasarnya telah dapat dikatakan sebagai pemenuhan restorative justice dimana merupakan konsep keadilan yang sedang ingin dicapai dalam pembaharuan hukum pidana di Indonesia. Oleh karena itu tujuan penulisan ini untuk menguraikan pentingnya bentuk perlindungan hukum kepada korban penipuan transaksi jual beli online dilihat dari perspektif Undang-Undang Informasi dan Transaksi Elektronik sekaligus untuk mendeskripsikan apakah ganti rugi sebagai pidana tambahan dapat ditetapkan sebagai upaya melindungi korban penipuan melalui transaksi jual beli online. Metode penelitian yang digunakan dalam tulisan ini adalah penelitian yuridis normatif dengan menggunakan pendekatan konseptual dan pendekatan perundang-undangan. Hasil penelitian dalam tulisan ini menunjukan bahwa Undang-Undang Informasi dan Transaksi Elektronik hanya mengatur tentang pidana pokok terhadap pelaku tindak pidana penipuan transaksi jual beli online dan tidak secara tegas mengatur tentang ganti rugi yang mestinya didapatkan oleh korban dari tindak pidana penipuan melalui transaksi jual beli online. Pentingnya ganti rugi dalam bentuk restutusi sebagai pidana tambahan agar supaya ganti rugi tidak hanya menjadi opsi untuk melindungi korban tetapi menjadi kewajiban untuk dipenuhi oleh setiap pelaku tindak pidana ketika tindak pidana yang dilakukannya berakibat kerugian bagi korban penipuan transaksi jual beli online.
\end{abstract}

Kata Kunci: Perlindungan Hukum;Korban Penipuan; Transaksi Jual Beli Online; Ganti Rugi.

\section{ABSTRACT}

Obligation to compensate victims basically could be said as a fulfillment of restorative justice which is the concept of justice that is being achieved in the renewal of criminal law in Indonesia. Therefore, the purpose of this paper is to describe the importance of legal protection for victims of online trading transaction fraud from the perspective of the Information and Electronic Transaction Law, also to describe whether compensation as an additional crime can be determined as an effort to protect victims of fraud through online trading transactions. The research method used in this paper is juridical normative, used a conceptual and statute approach. The results of this study indicate that the Electronic Information and Transaction Law only regulated the principal crimes against the perpetrators of fraudulent acts of online trading transactions and did not explicitly regulate the compensation that should be obtained by victims of fraudulent criminal acts through online buying and selling transactions. The importance of compensation in the form of restutution as an additional crime so that compensation is not only being an option to protect victims but also as the obligation which should be fulfilled by every criminal offender when their crimes had disadvantaged the victims of fraudulent online trading transactions.

Keywords: Legal Protection; Fraud Victims; Online Buying and Selling Transactions; Compensation 


\section{PENDAHULUAN}

\section{Latar Belakang}

Ilmu pengetahuan, teknologi dan seni mengantarkan manusia memasuki era digital yang melahirkan internet sebagai sebuah jaringan dan juga sebuah lambang eksklusivitas. ${ }^{1}$ Internet di gambarkan sebagai sekumpulan jaringan komputer yang terdiri dari sejumlah jaringan yang lebih kecil yang mempunyai sistem jaringan yang berbeda-beda. ${ }^{2}$

Dalam perkembangan selanjutnya kehadiran teknologi canggih komputer dengan jaringan internet telah membawa manfaat besar bagi manusia. Pemanfaatannya tidak saja dalam pemerintahan, dunia swasta/perusahaan, akan tetapi sudah menjangkau pada sektor kehidupan termasuk segala keperluan rumah tangga (pribadi). Internet telah mampu membuka cakrawala baru dalam kehidupan manusia baik dalam konteks sarana komunikasi dan informasi yang menjanjikan menembus batas-batas negara maupun penyebaran dan pertukaran ilmu pengetahuan dan gagasan di kalangan ilmuan di seluruh dunia. Akan tetapi, kemajuan tekhnologi informasi (internet) dan segala bentuk manfaat di dalamnya membawa konsekwensi negatif tersendiri dimana semakin mudahnya para penjahat untuk melakukan aksinya yang semakin meriasaukan masyarakat. ${ }^{3}$

Kemajuan internet sangat berperan pada bisnis online karena ciri hasnya adalah kepraktisan yang di tawarkan oleh internet itu sendiri. Dengan tidak betatap muka bisnis bisa dijalankan dan tidak di pungkiri prospek kedepannya akan cukup tinggi kerena dengan berbagai kelebihan yang

\footnotetext{
${ }^{1}$ Widodo. Hukum Pidana Di Bidang Teknologi Informasi. (Yogyakarta: Aswara Persindo, 2013), hal. 10
}

ditawarkan oleh bisnis online, dimana pun dan kapanpun proses penjualan bisa berjalan, oleh karena itu banyak yang memanfaatkan bisnis online ini untuk mejalankan aktifitas bisnisnya karena melihat internet sudah merupakan kebutuhan bagi semua lapisan masyarakat khusunya maksyarakat yang berada di perkotaan. Akan tetapi internet mempunyai dampak negatif khususnya pada masyarakat, tidak semua bisnis online berjalan seperti yang seharusnya, karena hanya dengan bermodalkan kepercayaan seringkali orangorang tidak menyianyiakan kesempatan ini untuk meraup keuntungan besar dengan melakukan kejahatan yaitu penipuan transaksi jual beli online. Dengan adanya kejahatan yang terjadi dalam proses bisnis online seakan mejadi hal baru yang harus mendapat perhatian serius dari pemerintah.

Indonesia telah mengesahkan Undang-Undang yang berkaitan dengan kejahatan dunia maya (cybercrime) khususnya Transaksi Elektronik yaitu Undang-Undang Nomor 19 Tahun 2016 Atas Perubahan Undang-Undang Nomor 11 Tahun 2008 Tentang Informasi dan Transaksi Elektronik Pasal 28 ayat (1) yang berbunyi: "Setiap orang dengan sengaja dan tampa hak menyebarkan berita bohong dan menyesatkan yang mengakibatkan kerugian konsumen dalan Transaksi Elektronik" dimana ancaman pidananya dituangkan dalam Pasal 45A ayat (1) yang berbunyi:

"Setiap orang dengan sengaja dan tanpa hak menyebarkan berita bohong dan menyesatkan yang mengakibatkan kerugian konsumen dalam Transaksi Elektronik sebagimana yang dimaksud dalam Pasal 28 ayat (1) dipidana dengan penjara pidana paling lama 6 (enam) tahun/atau denda paling banyak

\footnotetext{
${ }^{2}$ Maskun. Kejahatan Siber Cybercrime. (Jakarta: Kencana, 2013), hal. 64

${ }^{3}$ Ibid., hal. 47
} 
Rp1000.000.000 (satu milliar rupiah)"

\section{Undang-Undang Nomor 19 Tahun}

2016 menjadi payung hukum kepada masyarakat khusunya dalam transaksi jual beli online. Pasal 28 ayat (1) menjelaskan bagaimana unsur yang termasuk dalam kejahatan penipuan online. Penipuan online sebenarya sama dengan penipuan biasa, yang membedakan hanyalah medianya jual beli yaitu menggunakan elektronik.

munculnya Undang-Undang Nomor 19 Tahun 2016 atas Perubahan UndangUndang Nomor 11 Tahun 2008 Tentang Informasi dan Transaksi Elektronik memberikan dua hal yang penting yakni, pertama pengakuan transaksi elektronik dan dokumen elektronik dalam kerangka hukum perikatan dan hukum pembuktian, sehingga kepastian hukum transasksi elektronik dapat terjamin, dan yang kedua di klasifikasikan tindakan-tindakan yang temasuk kualifikasi pelanggaran hukum yang terkait penyalahgunaan TI (Teknologi Informasi) di sertai dengan sanksi pidananya. Namun, kadangkala konsumen masih saja dalam posisi lemah. Faktor utama yang menjadi kelemahan konsumen seringkali disebabkan karena tingkat pengetahuan hukum dan kesadaran konsumen akan haknya yang masih rendah, kondisi seperti ini oleh pelaku usaha dimanfaatkan untuk meraup keuntungan sebersar-besarnya dengan tidak mengidahkan kewajiban-kewajiban yang seharusnya sudah melekat pada para

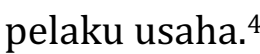

Dalam kasus penipuan online korban seringkali lebih menuntut ganti rugi yang berisfat meteril kepada si pelaku agar mendapatkan haknya di kembalikan karena kerugian yang di dapatkan oleh korban itu sendiri dan bentuk pertanggungjawaban pelaku penipuan online. Akan tetapi hal itu belum sepenuhnya terealisasikan karena belum ada yang secara sah mengatur tentang bagaimana ganti rugi kepada korban penipuan online itu sendiri.

Pentingnya ganti rugi kepada korban penipuan tranksaksi online merupakan ejahwantah tercapainya hakhak korban yaitu salah satu bentuk keadilan. Dalam Undang-Undang ITE dapat dilihat bahwa hanya ada satu pasal pidana pokok dan acaman pidana yang diberikan kepada pelaku tetapi belum menjelaskan bagaimana perlindungan kepada korban, perlindungan apa seperti apa yang bisa di dapatkan korban setelah kasus selesai dengan kerugian materil dan imateril diderita oleh korban.

Ganti rugi bagi korban yang dirugikan merupakan satu perlindungan hukum kepada korban dimana korban dapat mendapatkan kepastian, korban tidak hanya dilindungi dengan saksi hukum tetapi bagaimana tercapainya hak-hak korban setelahnya.

Ganti rugi itu sendiri hanya ada dalam kasus keperdataan, jika korban merasa perlu mendapatkan ganti rugi bisa membuat gugatan melalui jalur keperdataan, akan tetapi itu telihat sangat merugikan korban karena bisa dilihat bahwa korban telah dirugikan atas kerugian materi dan pengaduan melalui jalur pidana atas penipuan, terlebih jika di bebankan kembali atas gugatan ganti rugi lebih menimbulkan kerugian yang bekali-kali kepada korban, sehingganya sangat merugikan korban jika melihat dari sisi korban.

Korban bukan harus mendapat perlindungan dengan bagaimana tindak

\footnotetext{
${ }^{4}$ Setia Putra. 2014. "Perlindungan Hukum Terhadap Konsumen Dalam Transaksi Jual-Beli Melalui ECommerce." Jurnal Ilmu Hukum 5.2 : 197-208
} 
pidana itu diatur tetapi juga bagiamana korban setelahnya, apakah telah menjamin korban benar-benar terlindungi seutuhnya dan tercapainya hak-hak korban. Maka dari itu sangtlah menarik untuk melihat permasalahan ini dari Undang-Undang Informasi dan Transaksi Elektronik.

\section{Rumusan Masalah}

Adapaun rumusan masalahnya adalah;

1. Bagaimana bentuk perlindungan hukum kepada korban penipuan transaksi jual beli online dilihat dari perspektif Undang-Undang Informasi dan Transaksi Elektronik?

2. Apakah ganti rugi sebagai pidana tambahan dapat ditetapkan sebagai upaya melindungi korban penipuan transaksi online?

\section{Metode Penelitian}

Jenis Penelitian yang digunakan oleh peneliti dalam menyusun Penelitian ini adalah penelitian yuridis normatif dengan menggunakan pendekatan konseptual dan pendekatan perundang-undangan.

\section{PEMBAHASAN}

\section{Bentuk Perlidungan Hukum Kepada Korban Penipuan Transaksi Jual Beli Online Dilihat Dati Perspektif Undang-Undang Informasi Dan Transaksi Elektronik}

Adanya revisi UU ITE 2008 ke UU ITE 2016 memberikan salah satu rezim hukum baru yang masih sangat hangat dalam masyarakat untuk mengakomodir segala bentuk kejahatan di dalam ruang lingkup internet, akan tetapi terdapat beberapa kekosongon sekalipun telah dilakukan revisi atas UU ITE 2008. Dalam hal ini UU ITE 2016 belum sepenuhnya melakukan pembaharuan atas kejahatan-kejahatan dalam UU ITE, seperti belum melakukan pembaruan atas Pasal Transaksi Elektronik. Hal ini terlihat pada tidak adanya definisi khusus mengenai penjualan melalui sistem elektronik dalam UU tersebut, yang ada hanya "Transaksi Elektronik" yang memiliki definisi yang sangat luas yakni sebuah perbuatan hukum yang dilakukan dengan menggunakan komputer, jaringan komputer, dan/atau media elektronik lainnya. Disamping itu kecenderungan pembaharuan hukum pidana yang tidak lagi offender oriented tidak terlihat dalam UU ITE 2016 sebab sekalipun terjadi tindak pidana yang menimbulkan kerugian bagi korban, UU ITE 2016 tidak mengatur tentang ganti kerugian yang harusnya didapatkan oleh korban tindak pidana dalam hal ini korban dari kejahatan cyber/cybercrime, sebagai contoh dapat dilihat dari tindak pidana penipuan transaksi online dalam UU ITE 2016 yang diatur pada BAB VII Pasal 28, yaitu: "setiap orang dengan sengaja dan tanpa hak menyebarkan berita bohong dan menyesatkan yang mengakibatkan kerugian konsumen dalam Transaksi elektonik" Dengan ketentuan pidana pasal 45A ayat (1) dengan pidana penjara paling lama 6 (enam) tahun dan/atau denda paling banyak Rp.1.000.000.000,00 (satu miliar rupiah).

Tindak pidana ITE dalam Pasal 28 ayat (1) terdiri dari unsur-unsur berikut:

1. Kesalahan: dengan sengaja;

2. Melawan hukum: tanpa hak;

3. Perbuatan: menyebarkan;

4. Objek: berita bohong dan menyesatkan;

5. Akibat konstitutif: mengakibatkan kerugian konsumen dalam transaksi elektronik.

Mengenai penipuan melalui transaksi online, dalam UU ITE 2016 hanya mengatur tentang ketentuan pidana penjara maupun denda tanpa mengatur suatu kewajiban untuk memberikan ganti kerugian kepada korban dari tindak pidana penipuan tersebut. Padahal, setiap tahun kasus penipuan transaksi jual beli online meningkat. Peningkatan tersebut salah satunya adalah diakibatkan oleh minat 
masyarakat dalam menginginkan kepraktisan dalam berbelanja dan karena produk yang di tawarkan bermacam-macam dan secara praktis bisa di beli sehingga menimbulkan kenyamanan kepada masyarakat. Dengan pengaturan terkait penipuan yang tertuang dalam UU ITE 2016, korban akan sangat dirugikan sebab tidak didapatinya kewajiban ganti kerugian. Terlebih lagi, dalam transaksi online khususnya terkait dengan jual beli, posisi korban sangatlah lemah karena hanya dengan bemodalkan kepercayaan transaksi dapat dilakukan. Sehingga seringkali dijadikan kesempatan bagi sebagian orang untuk meraup keuntungan dalam proses transaksi jual beli online itu sendiri. Korban yang dimaksudkan disini adalah konsumen yang menerima barang.

Korban menjadi faktor penting bagi timbulnya suatu kejahatan, baik secara langsung maupun tidak langsung. Sebagaimana yang dikemukakakan oleh Mulyana W Kusuma ketika mengutip pendapat dari Hepered yang menyatakan: dalam study tentang kejahtan kekerasan terungkap bahwa acapkali korban memainmainkan peran kunci dalam interaksi kekerasan, bahkan tak jarang melakukan tindak provikasi terdahap orang lain ataupun balas dendam dengan pola kekerasan yang sering pula mengakibatkan luka dan kematian.

Kedudukan korban seakan telah di "diskriminasikan" oleh hukum pidana, padahal dalam konteks perbuatan hukum pidana, korban pada dasarnya merupakan pihak yang paling dirugikan. Oleh karena itu, mulai berkembang pemikiran yang menyuarakan agar orientasi hukum pidana di indonesia yang selama ini bersifat offender oriented, yaitu si pelaku kejahatan merupakan fokus utama dari hukum pidana, agar segera diubah. Perkembangan pemikiran dan perlunya perhatian terhadap korban didasari oleh dua pemikiran.
Pertama, pemikiran bahwa negara ikut bersalah dalam hal terjadinya korban dan selayaknya negara ikut bertanggungjawab dalam bentuk pemberian kompensasi atau restitusi. Kedua, adanya aliran pemikiran baru dalam kriminologi yang meninggalkan pendekatan positivis ke arah kriminologi kritis.

Bisnis online merupakan serangkaian kegiatan bisnis yang didukung oleh internet secara online. Setiap pelaku usaha yang sebagian atau seluruh aktivitas bisnisnya melalui internet secara langsung mereka dikatakan menjalankan bisnis online. Aktivitas bisnis online meliputi kegiatan jual beli online atau jasa secara online dan berbagai jenis yang dapat kita temukan diberbagai bidang industri.

Bisnis online itu sendiri selain memberikan kelebihan juga memberikan kelemahan kepada masyarakat yaitu:

Kelebihan bisnis online:

1. "Efisiensi modal, tidak diperlukan modal besar, karena tidak diperlukan infrakstuktur, hanya memerlukan biaya koneksi internet. Tendon barang tidak di perlukan dengan sarana yang luas, karena cukup dengan berkolaborasi dengan perusahaan, agen atau produsen, sehingga tida membutuhkan alokasi waktu yang lama;

2. Hemat waktu dan biaya, bisnis online dengan hitungan menit atau detik, sudah bisa diakan transaksi suatu barang, lain halnya dengan bisnis manual yang membutuhkan waktu yang lama, terlebih apabila antara penjual dan pembeli tempatnya berjauhan, atau lintas negara. Bisnis online pasti akan menghemat biaya, waktu dan tenaga. Untuk proses ijab qobul khususnya penyerahan barang dan jasa bisa menggunakan jasa ekspedisi;

3. Efisiensi tenaga, tidak memerlukan tenaga untuk menunggu dagangan, karena show room (ruang pamer) tidak diperlukan menggunakan ruangan cukup dengan show foto brang bdagangan dengan via elektronik;

4. Transaksi atau pembayaran via online, cukup menggunakan media lembaga 
keuangan

perbankan

dengan

menggunakan ATM, e-banking dan sejenisnya;

5. Tidak terbatas ruang dan waktu, bisa menjalankan bisnis dimanapun dan kapanpun asalkan tersedia perangkat koneksi yang terhubung dengan internet;

6. Biaya murah, biaya yang dibutuhkan jauh lebih murah dibandingkan dengan bisnis offline, karena tidak membutuhkan variable biaya;

7. Transaksi cepat proses pelayanan jauh lebih cepat, hal ini sesuai dengan prinsip bisnis yang membutuhkan kecepatan dan ketepatan;

8. Tenaga cukup irit, tenaga yang berperan sebagai pelayan hanya diperlukan sangat minim, karena yang mengoperasikan perangkatnya tidak diperlukan banyak tenaga." ${ }^{5}$

\section{Kelemahan bisnis online:}

1. "Pembayaran, bagi orang awam yang kurang mengenal teknologi informasi, pembayaran via online menjadi kendala berat, sudah tidak menguasai teknologi ditambah lagi tidak mempunyai sarana online. Padahal bila pembayaran belum dilakukan tidak mungkin barang dikirim. Bagi pembeli yang tidak peduli dengan kualitas barang akan mengalami kelemahan terlebih apabila pihak penjual ada unsur ketidakjujuran;

2. Barang yang tidak sesuai keinginan, barang yang dipajang hanya via media elektronik, bisa di mungkinkan terjadi perbedaan mutu artinya barang yang diterima tidak sama dengan yang dipesan atau tidak sesuaidengan barang yang dipajang;

3. Kesan masyarakan, karena banyaknya penipuan dalam bisnis online mengurangi kepercayaan masyarakat terhadap bisnis ini. Kerena sering terjadi pembeli telah mengirimkan sejumlah uang tetapi barang tidak dikirim;

4. Marak penipuan, bagi pelaku bisnis yang tidak mempunya perangkat pengaman, baik konsumen maupun produsen akan mudah diterobos oleh para penipu;

5. Peran dan fungsi hukum belum optimal dalam melindungi konsumen karena masih adanya konsumen yang ditipu oleh oknum pelaku bisnis online;

6. Pengguna internet belum untuk tingkat naisonal, pemakai perangkat internet masih rendah hal ini mempersulit untuk pengembangan bisnis online ditingkat daerah, khususnya daerah yang klasifikasi terpencil;

7. Penyelesaian sengketa antara penyedia barang/jasa dengan pengguna masih membutuhkan sistem yang solid." 6

Kelemahan bisnis online meposisikan konsumen seringkali terlanggar hak-haknya dan berada di posisi lemah dibandingkan dengan pelaku usaha. Kurangnya kesadaran akan hak dan kewajiban dari para pihak yang timbul dari transaksi elektronik terutama dalam perlindungan hukum konsumen. Pada praktiknya, ada yang mengharuskan konsumen untuk menanggung akibat dari membeli barang dan jasa yang ditawarkan oleh pelaku usaha.

Mekanisme transaksi elektronik di Indonesia sering kali menimbulkan kerugian terhadap korban. Bentuk kerugiannya adalah produk cacat, kelalaian bahkan korban penanggungan kerugian berupa kehilangan uang tanpa memperoleh barang yang di tawarkan, meskipun telah mengirimkan kewajiban untuk mengirimkan uang untuk pembelian barang tersebut.

Pada perlindungan konsumen, hukum memberikan perlindungan berupa hak kepada konsumen untuk melaksanakan kekuasaannya yaitu mengharuskan pelaku usaha untuk mengirimkan produk yang sudah dibayar. Pada praktiknya, ada pemahaman yang mengharuskan konsumen menanggung akibat dari pilihan yang diambilnya yaitu membeli produk berupa barang dan atau jasa yang ditawarkan oleh pelaku usaha. Hal tersebut mengakibatkan kedudukan konsumen menjadi lemah dari segi perlindungan hukum. 
Undang-Undang Informasi dan Transaksi Elektronik juga tidak menjelaskan tentang pengertian "konsumen" dan juga penegertian "perlindungan konsumen" dan belum memadai maka dari itu diperlukan perangkat peraturan untuk mewujudkan keseimbangan perlindungan kepentingan konsumen dan pelaku usaha sehingga tercipta perekonomian yang sehat.

$$
\text { Apabila konsumen telah }
$$

melaksanakan kewajiban membayar produk yang dipesan maka ia dapat konsumen dapat menggunakan haknya berupa kekuasaan untuk menuntut pelaku usaha melaksanakan kewajibannya menyerahkan produk yang sudah dibayar oleh konsumen. Pelaku usaha mempunyai hak relatif yaitu memperoleh pembayaran yang sudah disepakati oleh konsumen atas produk yang ditawarkan secara online. Selain hak, pelaku usaha juga mempunyai kewajiban yaitu pengiriman produk yang telah dibayar oleh konsumen.

Hak dan kewajiban timbul setelah terjadinya kesepakatan antara konsumen dan pelaku usaha dan berdasarkan kesepakatan antara konsumen dan pelaku usaha dan berdasarkan kesepakatan tersebut pelaku usaha memiliki hak untuk mendapatkan pembayaran yang merupakan kewajiban konsumen yang disertai dengan kewajiban pelaku usaha untuk menyerahkan barang yang sudah dibayar.

Pada tanggal 30 Maret 1999, Dewan Perwakilan Rakyat atau DPR telah menyepakati suatu rancangan undangundang atau RUU yang terkait dalam hal perlindungan konsumen yang tentunya disahkan oleh pemerintah yang ternyata selama 20 tahun selalu diperjuangkan. RUU ini ternyata baru disahkan oleh pemerintahpemerintah terkait pada tanggal 20 April

\footnotetext{
7 Susanto, Happy. Hak-Hak Konsumen Jika Dirugikan. (Jakarta: Visimedia, 2008), hal. 20

${ }^{8}$ Ibid.

9 Kompas. 16.000 Laporan Diterima Cek.Rekening.Id Penipuan Online Capai 14.000. 1109 2018. 2622019.
}

tahun 1999. Tentunya dengan diundangkannya hal tersebut, masalah yang terkait dengan perlindungan konsumen dapat dimungkinkan untuk melakukan pembuktian terbalik jika ternyata nantinya terjadi suatu sengketa diantara konsumen melawan pelaku usaha. Konsumen bila dalam hal ini merasa bahwa kepentingannya dilanggar dapat mengadukan ataupun memproses perkaranya melalui jalur hukum melalui Lembaga hukum yaitu Badan Penyelesaian Sengketa Konsumen. ${ }^{7}$

Di dalam UUPK juga dapat dilihat hakhak yang mestinya didapatkan oleh konsumen. Berdasarkan UUPK, perlindungan konsumen adalah suatu bentuk upaya yang akan menjamin terciptanya suatu kepastian hukum yang akan memberikan suatu perlindungan dalam hal ini bentuk perlindungannya terhadap konsumen, ada 4 (empat) macam hak ataupun kepentingan yang mendasar bagi konsumen, yakni sebagai berikut: ${ }^{8}$

a) "Hak ataupun suatu kepentingan untuk mendapatkan suatu bentuk keamanan (The right to be safety);

b) Hak mendapatkan informasi (The right to get information);

c) Hak untuk memilih (The right to choose necessary);

d) Hak ataupun kepentingan untuk didengar (The right to get heard)."

Berdasarkan data dari keminfo telah ada 16.678 laporan yang masuk ke situs tersebut, data per 11 september 2018 kata Pelaksana Tugas Kepala Biro Humas Kementrian Kominfo Ferdinandus Setu. Dari seluruh laporan tersebut hampir, $14.000 \mathrm{di}$ antaranya merupakan tindak kejahatan berupa penipuan transaksi jual beli online. ${ }^{9}$

Penangnanan kasus penipuan online

$<$ https://nasional.kompas.com/read/2018/09/11/15014481/ 16000-laporan-diterima-cekrekeningid-penipuan-onlinecapai-14000> 
di Indonesia setidaknya dapat dilihat dari beberapa kasus yang diputus di beberapa Pengadilan Negeri, seperti Pada Putusan Pengadilan Negeri Masamba Nomor 185/Pid.Sus/2014/PN Msb, dengan Terdakwa Musbah alias Andi Dwi Susanto alias Sarbini Bin Mangkerru, Terdakwa yang terbukti melakukan penipuan online dijatuhi hukuman berdasarkan ketentuan dalam Pasal 28 Ayat (1) UU ITE dimana Majelis Hakim menjatuhkan pidana terhadap Terdakwa dengan pidana 10 (sepuluh) bulan. Demikia halnya Pada Putusan Negeri Bantul Nomor 168/Pid.B/2015/ PN. Btl dengan Terdakwa Udika Als. Adit, Majelis Hakim menjatuhkan pidana terhadap Terdakwa dengan pidana penjara selama 1 (satu) tahun dan denda sebesar Rp. 10.000.0000,- (sepuluh juta rupiah) dengan ketentuan apabila denda tersebut tidak dibayar, akan diganti dengan pidana kurungan selama 2 (dua) bulan. Selanjutnya pada Putusan Pengadilan Negeri Sampang Nomor 128/Pid.B/2016/PN. Spg dengan Terdakwa Fajar Alfah Bin Mohammad Alwi Rais, Majelis Hakim menjatuhkan pidana terhadap Terdakwa selama 1 (satu) tahun dan 6 (enam) bulan.

Dari beberapa kasus diatas, dakwaan yang muncul selalu didasarkan pada Pasal 378 KUHP 10 dan Pasal 28 Ayat (1) UU ITE ${ }^{11}$. Dari rumusan keduanya perlu diketahui mengatur hal yang berbeda. Pasal 378 KUHP mengatur penipuan, sementara Pasal 28 Ayat (1) UU ITE mengatur mengenai berita bohong yang menyebabkan kerugian konsumen dalam transaksi elektronik. Walaupun begitu, kedua tindak pidana yang diatur dalam kedua pasal tersebut memiliki

\footnotetext{
${ }^{10}$ Barangsiapa dengan maksud untuk menguntungkan diri sendiri atau orang lain secara melawan hukum dengan menggunakan nama palsu atau martabat (hoedaningheid) palsu; dengan tipu muslihat, ataupun rangkaian kebohongan, menggerakkan orang lain untuk menyerahkan barang sesuatu kepadanya, atau supaya memberi utang maupun menghapuskan piutang, diancam, karena
}

satu kesamaan, yaitu dapat mengakibatkan kerugian bagi orag lain. Akan tetapi, rumusan Pasal 28 Ayat (1) UU ITE tidak mensyaratkan adanya unsur "menguntungkan diri sendiri atau orang lain" sebagaimana diatur dalam Pasal 378 KUHP tentang penipuan. Dalam penerapannya antara kedua pasal tersebut tentu diperlukan kejelian, namun yang perlu digaris bawahi adalah Pasal 28 Ayat (1) UU ITE lebih dikhususkan untuk tidak pidana yang merugikan konsumen dan dilakukan melalui transaksi online.

Selanjutnya dari putusan-putusan di atas, tidak di dapati satupun putusan yang menetapkan bahwa Terdakwa harus memberikan ganti kerugian kepada Korban tindak pidana penipuan online. Hal ini tidak terlepas dari proses pengajuan ganti kerugian yang mesti diajukan secara terpisah oleh Korban kepada Jaksa Penuntut Umum melalui proses penggabungan perkara selambat-lambatnya sebelum penuntut umum mengajukan tuntutan pidana $^{12}$ atau dengan menggunakan mekanisme Gugatan Perdata biasa dengan model gugatan Perbuatan Melawan Hukum dimana Korban harus menunggu adanya putusan pengadilan yang telah memutus perkara pidana yang dilakukan oleh Pelaku tidak pidana (Tergugat). ${ }^{13}$

Dengan demikian, apa yang diamanatkan dalam UUPK perihal hak-hak korban khususnya ganti kerugian akibat dari tindak pidana, hanya kan menjadi cita-cita UUPK dengan kecenderungan tidak dapat direalisasikan. Sebab dalam beberapa putusan terkait penipuan online, Majelis Hakim sama sekali tidak menyentil hak-hak

penipuan, dengan pidana penjara paling lama empat tahun. Pasal 378 KUHP

11 Setiap Orang dengan sengaja, dan tanpa hak menyebarkan berita bohong dan menyesatkan yang mengakibatkan kerugian konsumen dalam Transaksi Elektronik. Pasal 28 Ayat (1) UU ITE

12 Pasal 98 Ayat (1) dan (2) KUHAP

${ }^{13}$ Pasal 1365 KUHPerdata 
yang mestinya diberikan kepada korban tindak pidana seperti ganti kerugian sebagaimana yang diatur dalam UUPK.

Tidak terealisasinya ganti kerugian sekalipun sudah diatur dalam UUPK tidak dapat dilepaskan dari penggabungan perkara sebagai opsi untuk meminta ganti kerugian sebagaimana yang diatur di dalam KUHAP. ${ }^{14}$ Perlu diketahui pula, selain melalui penggabungan perkara, untuk menuntut ganti rugi dapat dilakukan dengan menggunakan gugatan perdata biasa dengan model gugatan perbuatan melawan hukum. Namun, kelemahan mekanisme ini adalah korban tindak pidana harus menunggu adanya putusan pengadilan yang telah memutus perkara pidana yang dilakukan oleh Pelaku (Tergugat). ${ }^{15}$

\section{Ganti Rugi Sebagai Pidana Tambahan Dapat Ditetapkan Sebagai Upaya Melindungi Korban Penipuan Transaksi Jual Beli Online}

Studi tentang kejahatan, tidak terdapat kejahatan yang tidak menimbulkan korban. Dengan demikian, korban adalah partisipan utama, meskipun pada sisi lain dikenal juga kejahatan tanpa korban "crime without victim", akan tetapi harus diartikan kejahatan yang tidak menimbulkan korban dipihak lain, misalnya penyalahgunaan obat terlarang, perjudian, aborsi, dimana korban menyatu sebagai pelaku. ${ }^{16}$

Dikatakan tanpa korban tidak mungkin terjadi suatu kejahatan. Jadi jelas bahwa, pihak korban adalah partisipan utama memainkan peranan penting. Bahkan setelah kejahatan dilaksanakan. Dalam masalah penyelesaian konflik dan penentuan hukuman bagi pihak pelaku,

\footnotetext{
14 Jika suatu perbuatan yang menjadi dasar dakwaan di dalam suatu pemeriksaan perkara pidana oleh pengadilan negeri menimbulkan kerugian bagi orang lain, maka hakim ketua sidang atas permintaan orang itu dapat menetapkan untuk menggabungkan perkara gugatan ganti kerugian kepada perkara pidana itu. Pasal 98 Ayat (1) KUHAP

15 Setiap perbuatan melawan hukum yang oleh karena itu menimbulkan kerugian pada orang lain, mewajibkan orang
}

dapat juga terjadi kejahatan yang dilakukan oleh pihak korban apabila dirasakan ada tindak lanjut yang tidak adil dan merugikan korban. ${ }^{17}$

Peranan korban kejahatan ini diantara lain berhubungan dengan apa yang dilakukan oleh pihak korban, bilamana dilakukan sesuatu, dimana hal tersebut dilakukan. Peranan korban ini mempunyai akibat dan pengaruh bagi diri korban serta pihaknya, pihak lain dan lingkungannya. Antara pihak korban dan pelaku terdapat hubungan fungsional. Bahkan dalam terjadinya kejahatan tertentu pihak korban dikatakan bertanggungjawab. ${ }^{18}$

Perlunya diberikan perlindungan hukum kepada korban kejahatan secara memadai tidak saja merupakan isu nasional, tetapi juga internasional. Oleh karena itu, masalah ini, perlu memperoleh perhatian yang serius. Pentingnya perlindungan korban kejahatan memperoleh perhatian serius, dapat dilihat dari dibentuknya Declaration of Basic Principal of Justice for Victims of Crime and Abuse of Power oleh Perserikatan BangsaBangsa, sebagai hasil dari The Sevent United Nation Conggres on the Prevention of Crime and Treatment of Ofenders, yang berlangsung di Milan, Italia, September 1985. ${ }^{19}$

Sepanjang menyangkut korban kejahatan dalam Deklarasi PBB tersebut telah menganjurkan agar paling sedikit diperhatikan 4 (empat) hal sebagai berikut:

1. "Jalan masuk untuk memperoleh keadilan dan diperlakukan secara adil (acces to justice and fair treatment);

2. Pembayaran ganti rugi (restitution) oleh

yang karena kesalahannya menyebabkan kerugian tersebut mengganti kerugian. Pasa 1365 KUHPerdata

${ }^{16}$ Rena Yulia, Viktimologi Perlindungan Hukum Terhadap Korban Kejahatan, (Yogyakarta, Graha Ilmu, 2010) hal: 76

${ }^{17}$ Ibid.

18 Ibid.

19 Ibid, HIm: 177 
pelaku tindak pidana kepada korban, keluarganya atau orang lain yang kehidupannya dirumuskan dalam bentuk sanksi pidana dalam perundangundangan yang berlaku;

3. Apabila terpidana tidak mampu, negara diharapkan membayar santunan (compensation) finansial kepada korban, keluarganya, atau mereka yang menjadi tanggungan korban;

4. Bantuan materiil, medis, psikologis dan sosial kepada korban, baik melalui negara, sukarelawan, masyarakat (assistance)."

Dalam perkembangan hukum pidana khususnya ketika muncul restorative justice, maka restitusi dipandang sebagai sebuah hukuman/tindakan untuk menyeimbangkan hilangnya hak-hak perdata dari korban yang dapat dinilai dengan uang. Restorative justice memberikan ruang yang besar bagi tercapainya kesepakatan antara korban pelaku, dan dalam konteks kesepakatan ini salah satu komponennya adalah pembayaran ganti rugi dari pelaku kepada korban atau keluarga korban atau ahli warisnya. ${ }^{20}$ Restitusi merupakan implikasi dari pergeseran paradigma pemidanaan; dari yang berorientasi kepada pembalasan (retributive justice) ke yang berorientasi pemulihan (restorative justice). Restitusi merupakan salah satu upaya untuk memenuhi kepentingan dan kebutuhan korban yang selama ini dilupakan dalam sistem peradilan pidana. ${ }^{21}$

Bila dilihat dari perspektif restoratve justice, yang menempatkan kejahatan adalah konflik orang perseorangan ${ }^{22}$, pemenuhan ganti rugi oleh pelaku kepada korban atau

20 Ahmad Sofian, Restitusi Dalam Hukum Positif Indonesia, Rubric of Faculty Members, https://businesslaw.binus.ac.id/2018/05/30/restitusi-dalam-hukum-positifindonesia/, diakses pada 1 September 2019

${ }^{21}$ Marcus A. Asner dalam Mahrus Ali. 2018. Kompensasi dan Restitusi Yang Berorientasi Pada Korban Tindak Korban Tindak Pidana, Jurnal Yuridika, Vol. 33 No. 2, hlm. 280 yang disebut sebagai restitusi merupakan hal yang harus dilakukan sebab kejahatan sebagai pelanggaran, pertama dan terutama melanggar hak perseorangan disamping juga melanggar hak masyarakat (kepentingan publik), kepentingan negara, dan juga sesungguhnya melanggar kepentingan pelanggar itu sendiri.

Kejahatan tidak lagi dikonsepsikan sebagai pelanggaran terhadap kepentingan negara, tetapi melanggar dan merugikan korban. ${ }^{23}$ Hal demikian dapat dilihat dalam beberapa peraturan perundang-undangan yang mencantumkan ketentuan perlindungan korban tindak pidana khususnya restusi.

Pengaturan tentang restitusi di Indonesia setidaknya terdapat dalam 7 (tujuh) undang-undang.

1. Undang-Undang Nomor 8 Tahun 1981 tentang Kitab Undang-Undang Hukum Acara Pidana (KUHAP), khususnya dalam Pasal 98-101;

2. Undang-Undang Nomor 26 Tahun 2000 tentang Pengadilan Hak Asasi Manusia, khususnya Pasal 35;

3. Undang-Undang Nomor 15 Tahun 2003 tentang Penetapan Peraturan Pemerintah Pengganti UndangUndang Nomor 1 Tahun 2002 tentang Pemberantasan Tindak Pidana Terosisme, khususnya dalam Pasal 3642;

4. Undang-Undang Nomor 31 Tahun 2014 tentang Perubahan Atas UndangUndang Nomor 13 Tahun 2006 tentang Perlidungan Saksi dan Korban, khususnya dalam Pasal 7A;

\footnotetext{
${ }^{22}$ Op. Cit., Rena Yulia, ... Hlm. 187

23 Juan Cardenas. 1986. The Crime Victim in The Prosecutorial Process. Harvard Journal of Law \& Public Policy. 9, 359-360, dalam Mahrus Ali. 2018 Kompensasi dan Restitusi Yang Berorientasi Pada Korban Tindak Korban Tindak Pidana. Jurnal Yuridika. Vol. 33 No. 2. hal. 262
} 
5. Undang-Undang Nomor 21 Tahun 2007 tentang Pemberantasan Tidnak Pidana Perdagangan Orang, khususnya melalui Pasal 48-50;

6. Undang-Undang Nomor 35 Tahun 2014 tentang Perubahan Atas UndangUndang Nomor 23 Tahun 2002 tentang Perlindungan Anak, khususnya melalui Pasal 71D; dan

7. Undang-Undang Nomor 11 Tahun 2012 tentang Sistem Peradilan Pidana Anak, khususnya melalui Pasal 10.

Perihal proses permohonan restitusi di Indonesia dapat dilakukan melalui tiga cara, yaitu: (1) melalui Penggabungan Perkara Ganti Kerugian; (2) melalui Gugatan Perbuatan Melawan Hukum; (3) dan melalui Permohonan Restitusi.

Penggabungan perkara ganti kerugian, secara khusus diatur dalam Bab XIII KUHAP yang mengatur dari Pasal 98 hingga Pasal 101. Pasal 98 ayat (1) KUHAP menentukan bahwa, "Jika suatu perbuatan yang menjadi dasar dakwaan di dalam suatu pemeriksaan perkara pidana oleh pengadilan negeri menimbulkan kerugian bagi orang lain, maka hakim ketua sidang atas permintaan orang itu dapat menetapkan untuk menggabungkan perkara gugatan ganti kerugian kepada perkara pidana itu." Untuk itu permohonan penggabungan perkara ganti kerugian berdasarkan ketentuan Pasal 98 Ayat (2) KUHAP diajukan selambatlambatnya sebelum penuntut umum mengajukan tuntutan pidana. Dalam hal penuntut umum tidak hadir, permintaan diajukan selambat-lambatnya sebelum hakim menjatuhkan putusan.

Pada saat korban tindak pidana meminta penggabungan perkara ganti kerugian maka Pengadilan wajib menimbang tentang kewenangannya

\footnotetext{
${ }^{24}$ liihat Pasal 99 Ayat (1) KUHAP

${ }^{25}$ lihat Pasal 99 Ayat (3) KUHAP.

${ }^{26}$ lihat Pasal 100 Ayat (1) KUHAP.
}

untuk mengadili gugatan tersebut, tentang kebenaran dasar gugatan dan tentang hukuman penggantian biaya yang telah dikeluarkan oleh korban. ${ }^{24}$ Putusan mengenai ganti kerugian dengan sendirinya akan mendapatkan kekuatan hukum tetap apabila putusan pidananya juga telah mendapat kekuatan hukum tetap. ${ }^{25}$ Begitu juga apabila Putusan terhadap perkara pidana diajukan Banding maka Putusan Ganti rugi otomatis akan mengalami hal yang sama. ${ }^{26}$ Namun, apabila perkara pidana tidak diajukan banding maka permintaan banding mengenai putusan ganti rugi tidak diperkenankan banding. ${ }^{27}$

Mekanisme

pemeriksaan penggabungan perkara ganti kerugian ini berdasarkan ketentuan Pasal 101 KUHAP menggunakan mekanisme yang diatur dalam Hukum Acara Perdata.

Selanjutnya, permohonan restitusi dilakukan dengan menggunakan Gugatan Perdata biasa dengan model gugatan Perbuatan Melawan Hukum. Dalam gugatan ini, Penggugat, dalam hal ini korban tindak pidana, tentu harus menunggu adanya putusan Pengadilan yang telah memutus perkara pidana yang dilakukan oleh Pelaku (Tergugat). ${ }^{28}$

Terakhir, permohonan restitusi dapat dilakukan melalui pengajuan permohonan kepada Lembaga Perlindungan Saksi dan Korban. Namun, pengajuan ini terbatas pada beberapa tindak pidana yang diatur dalam UndangUndang Nomor 13 Tahun 2006 tentang Perubahan Atas Undang-Undang Nomor 31 Tahun 2014 tentang Perlindungan Saksi dan Korban. Dimana secara teknis, diatur dalam PP No. 44 Tahun 2008 tentang Pemberian Kompensasi, Restitusi, dan Bantuan Kepada Saksi dan Korban dan

\footnotetext{
${ }^{27}$ lihat Pasal 100 Ayat (2) KUHAP

${ }^{28}$ Pasal 1365 KUHPerdata
} 
Peraturan Lembaga Perlindungan Saksi dan Korban Nomor 1 Tahun 2010 tentang Standar Operasional Prosedur Permohonan dan Pelaksanaan Restitusi.

Sekalipun telah diatur sedemikian rupa dalam beberapa ketentuan peraturan perundang-undangan, restitusi atau ganti kerugian tetaplah menjadi hanya menjadi opsi atau pilihan yang pengajuannya tergantung dari keinginan korban. Restitusi atau ganti kerugian belum menjadi kewajiban yang harus diperintahkan oleh peraturan perundangundangan untuk dipenuhi oleh pelaku tindak pidana terlepas dari apakah korban menginginkannya atau tidak.

Bila dilihat dari perspektif restoratve justice, yang menempatkan kejahatan adalah konflik orang perseorangan ${ }^{29}$, pemenuhan ganti rugi oleh pelaku kepada korban merupakan hal yang harus dilakukan sebab kejahatan sebagai pelanggaran, pertama dan terutama melanggar hak perseorangan disamping juga melanggar hak masyarakat (kepentingan publik), kepentingan negara, dan juga sesungguhnya melanggar kepentingan pelanggar itu sendiri.

Perlu diketahui, korban dalam beberapa tindak pidana secara umum sangat awam perihal ganti kerugian yang mestinya didapatkannya. Sehingga, karena ketidak tahunannya atas ganti kerugian tersebut, hak-hak yang mestinya didapatkan oleh korban melalui ganti kerugian atau restitusi tidak terpenuhi. Dengan realitas tersebut, pada akhirnya ada keadilan yang tidak dipenuhi sekalipun proses hukum terhadap pelaku tindak pidana telah berjalan dan telah diputus. Sebab proses dan putusan tersebut dapat dianggap tidak memperhatikan hak-hak yang mestinya didapatkan oleh korban. Seperti yang diatur dalam Pasal 19 Ayat (1) UUPK yang menyatakan bahwa, "Pelaku usaha bertanggung jawab memberikan ganti rugi atas kerusakan, pencemaran, dan atau kerugian konsumen akibat mengkonsumsi barang dan atau jasa yang dihasilkan atau diperdagangkan".

Oleh karena itu, menjadikan ganti kerugian sebagai pidana tambahan merupakan satu pilihan yang sangat logis untuk memenuhi hak-hak yang selama ini seringkali tidak didapatkan oleh korban dari tindak pidana sekalipun proses hukum teradap pelaku tindak pidana telah dilakukan.

Revisi UU ITE dengan memasukan ganti rugi dalam bentuk restitusi sebagai pidana tambahan juga akan menjamin terwujudnya kepastian hukum sebab setiap korban dari tindak pidana khususnya konsumen yang mengalami kerugian akibat transaksi jual beli online akan mendapat apa yang seharusnya menjadi haknya. Diaturnya ganti rugi dalam bentuk restitusi sebagai pidana tambahan dalam Revisi UU ITE akan menjelaskan bagimana politik hukum pidana kedepannya yang mengamanatkan adanya pembaharuan hukum pidana yang seharusnya berlaku dalam masyarakat.

\section{PENUTUP}

UU ITE hanya mengatur tentang pidana pokok terhadap pelaku tindak pidana penipuan transaksi jual beli online. Dari beberpa kasus terkait penipuan transaksi jual beli online, secara umum tidak memutus ganti rugi dalam bentuk restitusi yang mestinya diberikan kepada korban akan tetapi hanya memutus pidana pokok terhadap pelaku tindak pidana. Hal ini terjadi tidak terlepas dari permohonan ganti rugi dalam bentuk restitusi hanya sebagai pilihan dalam sistem hukum pidana Indonesia sekarang. Setidaknya

${ }^{29}$ Ibid., Hlm. 187 
dapat dilihat dalam Pasal 98-101 KUHAP, Pasal 1365 KUHPer. Kewajiban restitusi hanya terbatas pada tindak pidana tertentu sebagaimana diatur dalam UU Perlindungan Saksi dan Korban. Padahal restitusi terhadap korban telah dapat dikatakan sebagai pemenuhan restorative justice dimana merupakan konsep keadilan yang sedang ingin dicapai dalam pembaharuan hukum pidana di Indonesia.

Ganti rugi dalam bentuk restitusi sebagai pidana tambahan merupakan satu pilihan yang sangat logis untuk memenuhi hak-hak yang selama ini seringkali tidak didapatkan oleh korban dari tindak pidana sekalipun proses hukum teradap pelaku tindak pidana telah dilakukan. Restitusi yang hanya menjadi opsi dan posisi korban yang pada umumnya awam perihal restitusi mengharuskan restitusi untuk diatur sebagai pidana tambahan. Dilihat dari perspektif restoratve justice, dimana merupakan konsep yang sudah dipakai di beberapa peraturan perundang-undangan di Indonesia, menempatkan kejahatan adalah konflik orang perseorangan sehingga pemenuhan ganti rugi oleh pelaku kepada korban atau yang disebut sebagai restitusi merupakan hal yang harus dilakukan sebab kejahatan sebagai pelanggaran, pertama dan terutama melanggar hak perseorangan disamping juga melanggar hak masyarakat (kepentingan publik), kepentingan negara, dan juga sesungguhnya melanggar kepentingan pelanggar itu sendiri.

\section{REFERENSI}

\section{Buku}

Maskun. (2013). Kejahatan Siber Cybercrime. Jakarta: Kencana.

Susanto, Happy. (2008) Hak-Hak Konsumen Jika Dirugikan. Jakarta: Visimedia.
Widodo. (2013) Hukum Pidana di Bidang Tekhnologi Informasi. Yogyakarta: Aswada Persindo.

Yulia, Rena. (2010) Viktimologi Perlindungan Hukum Terhadap Korban Kejahatan. Yogyakarta: Graha Ilmu.

\section{Artikel Jurnal}

Ali, Mahrus \& Wibowo, A. (2018). "Kompensasi dan Restitusi Yang Berorientasi Pada Korban Tindak Korban Tindak Pidana." Yuridika, 33 (2)

Putra, Setia. (2014). "Perlindungan Hukum Terhadap Konsumen Dalam Transaksi Jual-Beli Melalui ECommerce." Jurnal Ilmu Hukum 5. (2), 197-208.

\section{Web Resmi}

Kompas, 16.000 Laporan Diterima Cek.Rekening.Id Penipuan Online Capai 14.000,

https://nasional.kompas.com/read/2 018/09/11/15014481/16000laporan-diterima-cekrekeningidpenipuan-online-capai-14000, diakses pada tanggal 26-02-2019, pukul 21:24 WIB

Sofian, Ahmad, Restitusi Dalam Hukum Positif Indonesi, Rubric of Faculty Members, https://businesslaw.binus.ac.id/2018/0 5/30/restitusi-dalam-hukum-positifindonesia/, diakses pada 1 September 2019

\section{Undang-Undang}

Kitab Undang-Undang Hukum Perdata

Undang-Undang Dasar Negara Republik Indonesia Tahun 1945

Undang-Undang Nomor 1 Tahun 1946

Tentang Kitab Undang-Undang Hukum Pidana

Undang-Undang Nomor 8 Tahun 1981 
Tentang Kitab Undang-Undang Hukum Acara Pidana

Undang-Undang Nomor 11 Tahun 2008

Tentang Informasi dan Transaksi

Elektronik 